\title{
Convención Revolucionaria y Congreso Constituyente
}

\author{
Luciano Ramírez Hurtado ${ }^{1}$
}

\begin{abstract}
Resumen
Luego de ser derrocado el régimen del dictador Victoriano Huerta, en julio de 1914, las distintas fuerzas revolucionarias (carrancistas, villistas, zapatistas) empezaron a tener diferencias por lo que acordaron reunirse para realizar una Convención con el propósito de evitar la escisión, acordar cambios drásticos en la dirección política del Estado, debatir los problemas socioeconómicos y políticos más importantes que aquejaban a la nación. Las propuestas que los delegados sometieron a discusión en las distintas etapas de la Soberana Convención Revolucionaria, fueron configurando el documento denominado Programa de Reformas Político-Sociales de la Revolución, algunas de las cuales -de manera indirectafueron retomadas por los diputados constituyentes de Querétaro e influyeron para concretar los artículos fundamentales de la Carta Magna que actualmente rige los Estados Unidos Mexicanos. El objetivo de este trabajo es tratar de establecer algunas relaciones entre la Convención, considerada como asamblea nacional preconstituyente, y la Constitución de 1917.
\end{abstract}

Palabras clave: Revolución mexicana, Soberana Convención, Constitución política.

\begin{abstract}
After the regime of the dictator Victoriano Huerta was overthrown in July 1914, the different revolutionary forces (carrancistas, villistas, zapatistas) began to have differences so they agreed to meet to carry out a Convention with the purpose of avoiding the split, agreeing to changes drastic in the political direction of the State, to debate the most important socioeconomic and political problems that afflicted the nation. The proposals that the delegates submitted to discussion in the different stages of the Sovereign Revolutionary Convention, were configuring the document called Program of Political-Social Reforms of the Revolution, some of which - indirectly - were taken up by the constituent deputies of Querétaro and influenced to materialize the fundamental articles of the Magna Carta that presently governs the Mexican United States. The purpose of this paper is to try to establish some relations between the Convention, considered as a preconstituent national assembly, and the Constitution of 1917.
\end{abstract}

Key words: Mexican Revolution, Sovereign Convention, Political Constitution.

\section{Recibido en: 05/07/2017}

Aprobado en: 05/11/2017

\footnotetext{
${ }^{1}$ Doctor en Historia del Arte, Departamento de Historia del Centro de Ciencias Sociales y Humanidades de la Universidad Autónoma de Aguascalientes, Av. Universidad No. 940, Col. Universitaria, C.P. 20131, Aguascalientes, Ags., México, tel. 44991084 81; lramirez@correo.uaa.mx
}

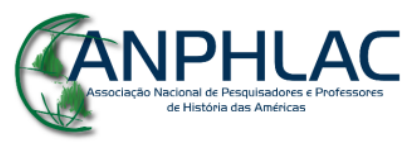

Revista Eletrônica da ANPHLAC, ISSN 1679-1061, №. 23, p. 05-28, Jul./Dez., 2017.

http://revista.anphlac.org.br 


\section{Convención Revolucionaria}

La ciudad de Aguascalientes fue elegida, en octubre de 1914, como sede para realizar la Convención Revolucionaria. En ese foro de discusión se replantearon diversos temas trascendentales para el país y se propusieron nuevas orientaciones y soluciones para diseñar un proyecto de nación diferente. Como parte fundamental, se pretendía construir el nuevo Estado nacional emanado de la Revolución mexicana para renovar el régimen político y la forma de gobierno (QUIRK, 1989, p. 36-107; AMAYA, 1975, p. 82-443). Por distintas circunstancias, el organismo se volvería itinerante, pasaría por distintas ciudades hasta su disolución un año más tarde.

La Convención fue ante todo un intento de negociación política entre las facciones revolucionarias, aunque también significó una disputa por el poder, un enfrentamiento por imponer su hegemonía y una lucha por el Estado. Representó la asamblea nacional de discusión que precedió al enfrentamiento militar interrevolucionario, a la que acudieron las distintas facciones con el objetivo de presentarse, identificarse, reconocerse, y ponerse a prueba; de alguna forma este escenario institucional logró aglutinar a las principales corrientes revolucionarias, conformadas de la coalición antihuertista, para que midieran sus respectivas fuerzas políticas e ideológicas.

La Soberana Convención de Aguascalientes parecía ser el germen de un Estado nacional, en el que había que hacerse presente para ganar espacios políticos e imponer supremacía. En esta disputa por el Estado, los tres principales gobiernos en desarrollo: el constitucionalista, el villista, y el zapatista, nos dice Felipe Arturo Ávila Espinosa -sin duda el máximo especialista en el tema-, "para poder ser nacionales y soberanos tenían que imponerse como uno solo, triunfador sobre los demás" (1991, p. 92).

\section{Fotoperiodistas en Aguascalientes}

En octubre de 1914, repentinamente, Aguascalientes se convirtió en el foco de atención de todo el país y acaparó la atención pública. Los revolucionarios de las distintas facciones, la prensa y la opinión pública volvieron su mirada expectante hacia la capital hidrocálida. De inmediato los principales diarios de la prensa capitalina mandaron sus

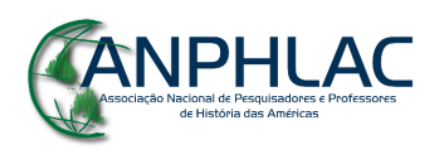

Revista Eletrônica da ANPHLAC, ISSN 1679-1061, №. 23, p. 05-28, Jul./Dez., 2017.

http://revista.anphlac.org.br 
enviados especiales. Fotógrafos y periodistas hicieron maletas y se prepararon con todo el equipo necesario para estar presentes en el lugar de los hechos y cubrir la nota. El seis de octubre partieron en tren especial, de la estación del Central, en Buenavista, junto con algunos delegados, representantes de los periódicos que iban a "reseñar la Convención". Se conocen los nombres de Carlos F. Muñana, de El Liberal, Arturo Cisneros Peña, enviado especial del recién fundado diario El Pueblo; días después llegaron Heliodoro J. Gutiérrez y Agustín Víctor Casasola, quienes publicaron sus fotos en la revista La Ilustración Semanal.

El objetivo e interés de los periódicos era la foto política, en donde aparecieran los personajes de actualidad más prominentes en el escenario de la política nacional, reunidos en la ciudad donde se celebraba la Convención. Estaba en marcha, desde luego, la nueva fotografía oficialista o "de bronce", pues había que fotografiar a las figuras del momento, lo mismo en sus hoteles que en momentos de ocio, y desde luego durante los debates y momentos solemnes de las sesiones.

La sede de la Convención de Aguascalientes fue el Teatro Morelos. Las autoridades correspondientes dieron a los fotógrafos, reporteros y corresponsales pases para tener acceso y les asignaron un sitio estratégico: una de las plateas inmediatas al escenario se apartó para ellos, desde donde pudiesen ver claramente a los delegados durante sus intervenciones, tomar fotos de los momentos importantes y escuchar cada palabra pronunciada en las deliberaciones. Aunque les fue destinado un lugar específico a los fotoperiodistas, éstos se movieron libremente en el interior del teatro, para tomar fotografías desde distintos ángulos y alturas. De esa manera captaron votaciones, nombramiento de la nueva mesa directiva, declaración de la soberanía, solemne juramento, firma e incidente de la bandera, ${ }^{2}$ toma de protesta del nuevo Presidente provisional, etc. Los fotógrafos utilizaban flash en interiores con magnesio de polvo, lo que provocaba un disparo de olor nauseabundo y una luz cegadora; por ello los fotografiados salían con posturas ridículas,

\footnotetext{
${ }^{2}$ Se conoce como incidente de la bandera al episodio que, tras la llegada de los zapatistas, tuvo lugar el 27 de octubre de 1914, cuando hizo uso de la palabra el licenciado Antonio Díaz Soto y Gama, personaje de ideas anarco-sindicalistas; mientras pronunciaba su discurso el delegado del Ejército Libertador del Sur, tocó y al parecer jaloneó varias veces la bandera mexicana que estaba al lado de la tribuna, asegurando que ésta simbolizaba la reacción, el conservadurismo, el clericalismo decimonónico y la intriga del grupo carrancista, provocando con ello la molestia de muchos delegados quienes se sintieron ofendidos e interpretaron que era una falta de respeto zarandear la enseña nacional. Los periodistas y varios autores aseguran que vociferaron y gritaron al osado orador, además de que salieron a relucir las armas y estuvieron a punto de dispararle, a la vez que, amenazantes, se apuntaban unos a otros; luego de varios minutos la mesa directiva llamó al orden, se tranquilizaron los ánimos y continuó la discusión. Ver RAMÍREZ, 2010, p. 106-111
}

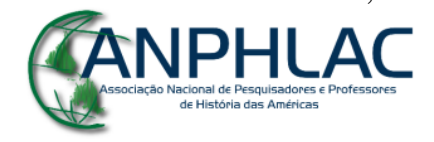

Revista Eletrônica da ANPHLAC, ISSN 1679-1061, №. 23, p. 05-28, Jul./Dez., 2017.

http://revista.anphlac.org.br 
desviaban la mirada o entrecerraban los ojos. Por otro lado, la fotografía de prensa de la época carecía de nitidez y definición, debido a que la fotomecánica acusaba tonos grises y sin contraste, lo que dificultaba la plena identificación de los personajes. (RAMÍREZ, 2010, p. $50,52,75,80-90,120-121)$.

EI Manifiesto-Programa de la Convención a la Nación, del 14 de noviembre de 1914 en Aguascalientes

Desde el 17 de octubre se constituyó en la Convención la Comisión de Programa, que días más tarde quedó integrada por nueve delegados pertenecientes a los distintos grupos, con el objeto de recoger las propuestas y principios de todos los grupos revolucionarios y con ello definir el programa de gobierno revolucionario, mismo que debía ser respetado por el próximo candidato a la Primera Magistratura del país (BARRERA, 1977 , p. 380-387, 406, 407, 437, 469-470, 472, 473). De forma deliberada, los miembros de la Comisión del programa no hicieron nada al respecto porque tenían la consigna de esperar a que llegaran los zapatistas. Por lo demás, pasarían muchas semanas más para que los convencionistas discutieran, a fondo, las cuestiones relacionadas con el programa de gobierno.

\section{GANPHLAC}




\section{FIGURA 1}

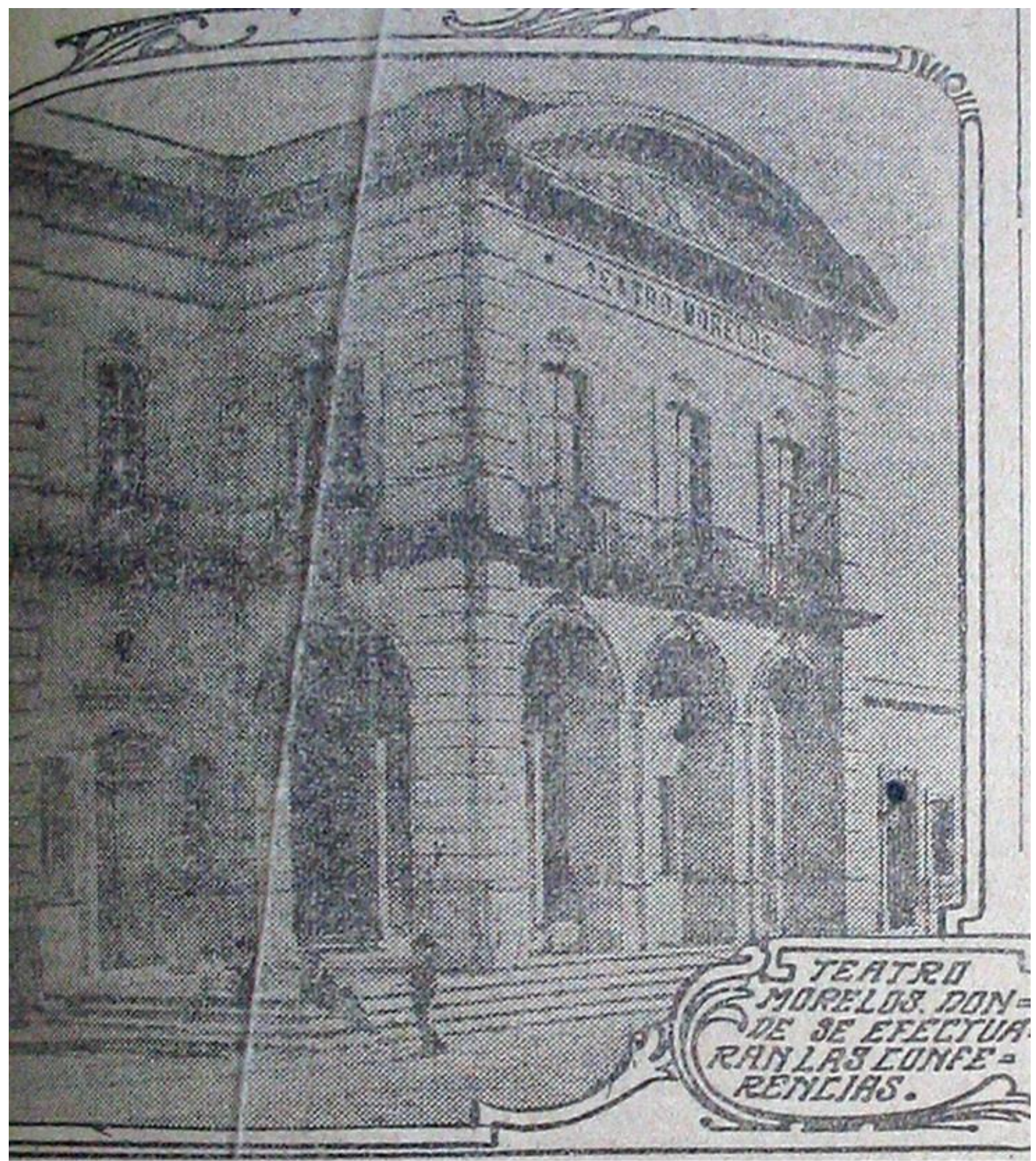

Teatro Morelos de Aguascalientes. Foto de prensa.

Autor Carlos F. Muñana. El Liberal, México, D.F., 10 de octubre de 1914, p. 1.

Muchos delegados estaban convencidos que ese organismo era el germen de un Estado nacional, la instancia más auténtica, representativa y democrática de la Revolución y por eso creyeron que valía la pena mantenerse en ella. En su seno se discutirían las reformas que el nuevo gobierno revolucionario tendría que llevar al terreno de la práctica. Pensaban

\section{GANPHLAC}

Revista Eletrônica da ANPHLAC, ISSN 1679-1061, №. 23, p. 05-28, Jul./Dez., 2017.

http://revista.anphlac.org.br 
que habían adquirido una gran responsabilidad ante la historia, como dijo David G. Berlanga $^{3}$ "ante la civilización y ante la humanidad", y a todos los allí reunidos correspondería dar forma a "las aspiraciones y actividades de todo un pueblo, en el sentido de un acuerdo legal" (1914, p. 94).

Por otro lado, ha pasado prácticamente desapercibido para los estudiosos un manifiesto a la nación, fechado el 14 de noviembre de 1914 en Aguascalientes, firmado por el general villista Roque González Garza (representante personal del general Francisco Villa), así como por los generales constitucionalistas Martín Espinosa, José Inocente Lugo y el doctor Felipe Gutiérrez de Lara. El documento es un programa mínimo de gobierno, una síntesis de los principios y tendencias de los grupos revolucionarios, representados en la Convención, que se dieron cita en el Teatro Morelos, esto es, villistas, zapatistas y carrancistas independientes; los incisos del "Manifiesto-Programa de la Convención a la Nación", ${ }^{4}$ son los siguientes:

Primero.- Destruir el latifundio, desamortizando la gran propiedad rural y repartiéndola entre la población que hace producir la tierra con su esfuerzo individual.

Segundo.- Devolver a los pueblos los ejidos de que fueron despojados durante las pasadas dictaduras.

Tercero.- Castigar a los enemigos de la Revolución por medio de la confiscación/ nacionalización de sus bienes.

Cuarto.- Realizar la independencia de los Municipios, sobre la base de una amplia libertad de acción, que les permita atender debidamente los intereses comunales y preservara éstos de las usurpaciones y ataques de los gobiernos federal y local.

Quinto.- Restringir las facultades del Poder Ejecutivo de la Federación y de los Estados y para ello adoptar el parlamentarismo en forma adecuada a las especiales condiciones del país.

Sexto.- Hacer efectivas las responsabilidades en que incurran los altos funcionarios que falten al cumplimiento de sus obligaciones, expidiendo las leyes necesarias para definirlas y para establecer, de un modo preciso, las relaciones que deben existir entre esos funcionarios y el pueblo.

\footnotetext{
${ }^{3}$ David G. Berlanga (1884-1914) fue un profesor normalista, originario del estado de Coahuila, educado en Saltillo, ciudad de México y varias universidades europeas, que se incorporó a la revolución en 1912; se desempeñó como delegado en la Soberana Convención, representando al gobernador de Aguascalientes, donde expresó libremente sus ideas y propuso un paquete de reformas educativas, económicas, políticas y sociales al futuro gobierno; fue ejecutado el 8 de diciembre por órdenes del general Francisco Villa, pues éste se enteró que era criticado por el delegado norteño. Ver RAMÍREZ, 2004, p. 27-282.

${ }^{4}$ Los once puntos, en CERVANTES, 2000, p. 346-347; este autor menciona que el manifiesto fue publicado en el periódico oficial La Convención, diario identificado con los ideales de la Soberana Convención Revolucionaria, México, Tomo I, número 26, del 30 de diciembre de 1914; los primeros nueve puntos reproducidos en MEDELLÍN, 2004, p. 143-144. Curiosamente nada se dice de dicho "Manifiesto-Programa", ni fue reproducido en las Crónicas y debates de la sesiones de la Soberana Convención Revolucionaria, compiladas por Florencio Barrera Fuentes, publicadas por el INEHRM en 1965 en tres tomos, con motivo de las conmemoraciones cívicas, y reeditadas en 1977.
}

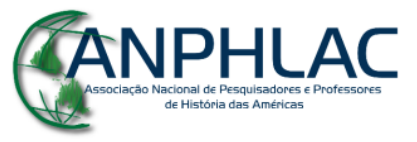

Revista Eletrônica da ANPHLAC, ISSN 1679-1061, №. 23, p. 05-28, Jul./Dez., 2017.

http://revista.anphlac.org.br 
Séptimo.- Reorganizar sobre nuevas bases el Poder Judicial para obtener la independencia, aptitud y responsabilidad efectiva de sus funcionarios.

Octavo.- Formular las reformas que reclama con urgencia el Derecho Común, adaptándolo a las necesidades sociales y económicas del país; derogando su formulismo tradicional e innecesario, así como su embarazosa tramitación; expidiendo las leyes que sean necesarias para que sea efectiva y oportuna la administración de justicia, evitando que en ella encuentren una defensa inexpugnable el concesionario o el contratista de mala fe; y [expidiendo] aquellas [leyes] que constituyen una protección justiciera y efectiva para la clase humilde.

Noveno.- Atender a las necesidades de la instrucción que reclaman nuestras clases humildes, sin omitir para ello ningún sacrificio, y a las económicas y morales de la clase trabajadora, a la que se reconocerá del modo más amplio su libertad de asociarse y declararse en huelga para la defensa de sus intereses, amenazados por la absorción capitalista.

Décimo.- Dictar las disposiciones que hayan de hacer verdaderamente efectivas las libertades humanas, dentro de los límites de la convivencia social.

Undécimo.- Procurar hacer efectiva la soberanía popular, buscando el equilibrio en los poderes públicos, para evitar nuevas dictaduras.

La discusión propiamente dicha del programa de gobierno de la Revolución se llevaría a cabo hasta el año siguiente, de enero a septiembre de 1915. Tras la llegada de los zapatistas y la adopción del Plan de Ayala por la Convención comenzaba su supremacía ideológica en ese organismo. En breve se pondrían en marcha las ideas que formaron parte del Programa de Reformas Político-Sociales de la Revolución, documento expedido por la Soberana Convención Revolucionaria, en 1915, y mejorado a principios del año siguiente hasta su publicación en Jojutla, Morelos en abril de 1916.

\section{Las etapas de la Convención y el Programa de Reformas Político Sociales de la Revolución, preludio del Constituyente}

La Convención Revolucionaria es un organismo muy difícil de comprender, pues cambió de sede en varias ocasiones, fue modificando su composición y, por lo tanto, reorientando sus objetivos, a lo largo de cinco etapas, de acuerdo a las circunstancias. Seguir el debate de las ideas, por lo tanto, tiene sus dificultades porque una serie de eventos políticos alteraban, con frecuencia, de manera radical la realidad política del momento.

A la primera etapa de la capital no acudieron villistas (por desconfianza) ni zapatistas (no fueron invitados), solo carrancistas. Entre los acuerdos más importantes estuvo el no

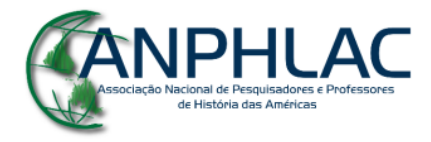

Revista Eletrônica da ANPHLAC, ISSN 1679-1061, №. 23, p. 05-28, Jul./Dez., 2017.

http://revista.anphlac.org.br 
aceptar la renuncia de Venustiano Carranza como Primer Jefe y Encargado del poder Ejecutivo, la exclusión de los civiles de los debates y el traslado a la ciudad de Aguascalientes (ALESSIO, 1989, p. 103-120; AMAYA, 1975, p. 75-102).

La etapa de Aguascalientes, la segunda, propiamente no fue la más rica en materia de discusión pero si la más apasionante y representativa pues en el Teatro Morelos se dieron cita delegados de las facciones carrancista, villista, zapatista así como de otros grupos independientes; en esa ciudad se declaró a la Convención como órgano soberano el 14 de octubre, esto es, como la máxima autoridad del país; tras la llegada de los enviados del Ejército Libertador del Sur, son ellos quienes le dan un nuevo giro ideológico a los debates, ya que hasta antes del 27 de octubre de 1914 no se había discutido todavía ninguna idea importante de la Revolución, todo se había reducido a declaraciones de buenas intenciones y escarceos políticos; los sureños traían la consigna de que para que ellos pudieran formar parte de la asamblea tenía que suceder dos cosas: por un lado acordar la eliminación del "hombre estorbo" de la Revolución (Carranza) y por el otro aceptar la adopción en lo general del Plan de Ayala; ambas cosas las consiguieron con gran facilidad. Luego de que la Convención decidió cesar en sus puestos a Venustiano Carranza como Primer Jefe y Encargado del Poder Ejecutivo, y a Francisco Villa como Jefe de la División del Norte por considerar que éste era parte sustancial del problema, la discusión ideológica se interrumpió por espacio de dos meses. En Aguascalientes, además, se nombró al general Eulalio Gutiérrez como Presidente provisional de la República. (ALESSIO, 1989, p. 125-326; AMAYA, 1975, p. 105-172).

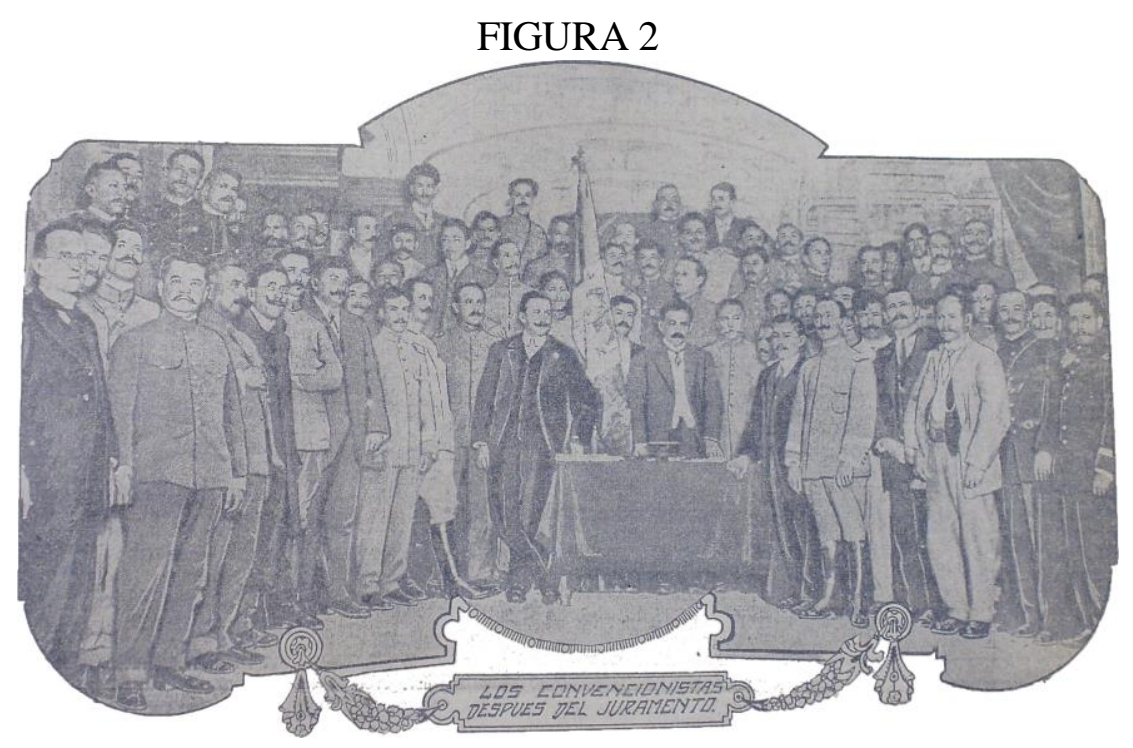

La Convención Revolucionaria de Aguascalientes se declara soberana. "Los convencionistas después del juramento", El Liberal, México, D.F., 17 de octubre de 1914, p. 1. Autor Carlos F. Muñana.

\section{CANPHLAC}

Revista Eletrônica da ANPHLAC, ISSN 1679-1061, №. 23, p. 05-28, Jul./Dez., 2017.

http://revista.anphlac.org.br 
FIGURA 3

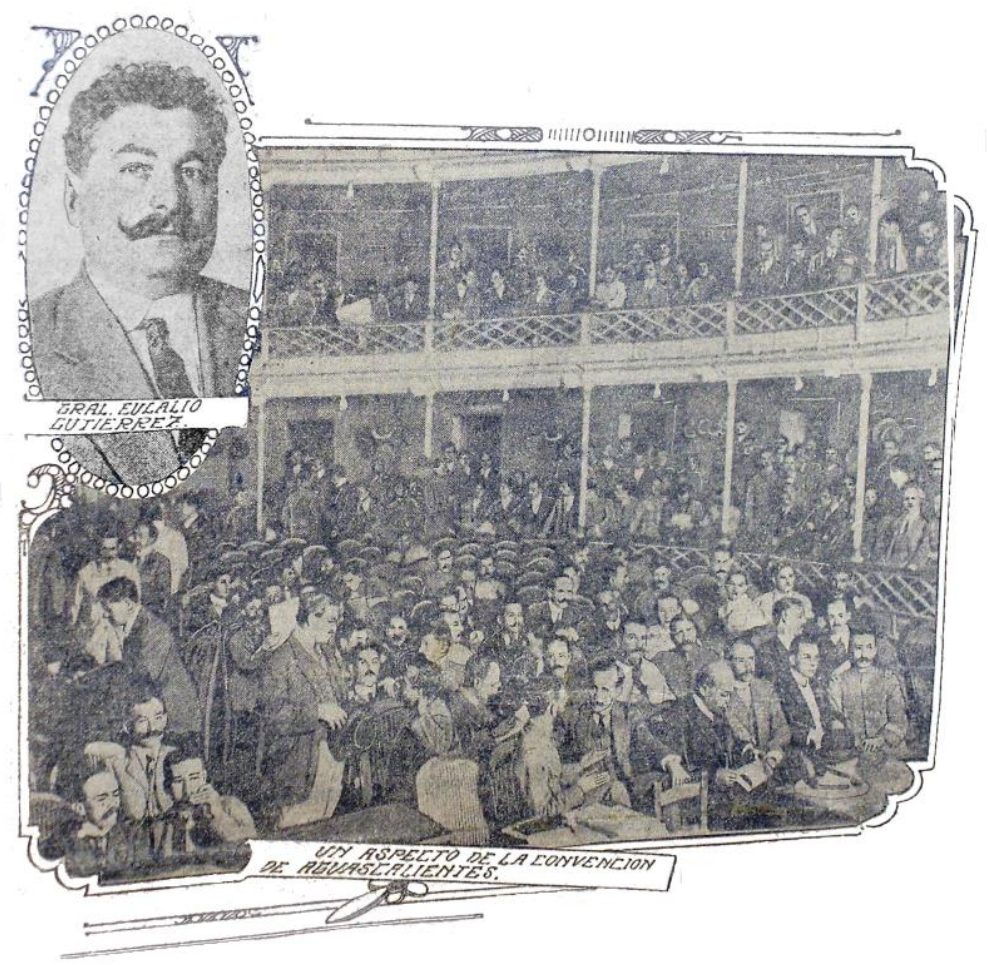

Presidente provisional de la República. "Gral. Eulalio Gutiérrez" y "Un aspecto de la Convención de Aguascalientes”, El Liberal, México, D.F., 8 de noviembre de 1914, p. 1. Autor Carlos F. Muñana.

Fue hasta enero de 1915, en su tercera etapa -nuevamente en la Ciudad de México-, cuando se reanudó la discusión en torno al Programa de Gobierno. La Convención quedó conformada solamente por delegados villistas y zapatistas, pues los carrancistas se habían retirado. El tema del parlamentarismo como régimen político cobró fuerza luego de la defección de Eulalio Gutiérrez, pero la Soberana Convención se tiene que mudar a Cuernavaca, Morelos, donde los delegados por cuestiones ideológicas, se dividen en dos partidos: el Norte (villistas) y el Sur (zapatistas). A finales de febrero, en esa ciudad, -en su cuarta etapa-, bajo la hegemonía de los sureños, se comienza a discutir de manera más amplia y cuidadosa el Proyecto de Reformas de la Revolución, aunque fue hasta la primera decena del siguiente mes cuando ese organismo toma acuerdos relevantes al aprobar la destrucción de los latifundios, la devolución de ejidos a los pueblos despojados de ellos, la creación de bancos agrícolas, realización de obras de comunicación y de irrigación para el fomento de la agricultura; asimismo quedaron prohibidos los monopolios, en lo que respecta al control de los recursos naturales (la cuestión del petróleo y la legislación minera, por ejemplo); por esos días se tocan temas en torno a la supresión de la vicepresidencia, la autonomía de los municipios y

\section{CANPHLAC}

Revista Eletrônica da ANPHLAC, ISSN 1679-1061, №. 23, p. 05-28, Jul./Dez., 2017.

http://revista.anphlac.org.br 
el sistema del voto directo. Dos horas diarias dedicaban a discutir las cuestiones del programa cuando se agotaba el tiempo y debían pasar a otros asuntos. El 11 de marzo se suspendieron los debates en Cuernavaca para trasladar el gobierno de la Convención a la Ciudad de México y reanudar sesiones el día 21 de ese mes (AMAYA, 1975, p. 190-193, 200-203, 206, 212-232, 238-244).

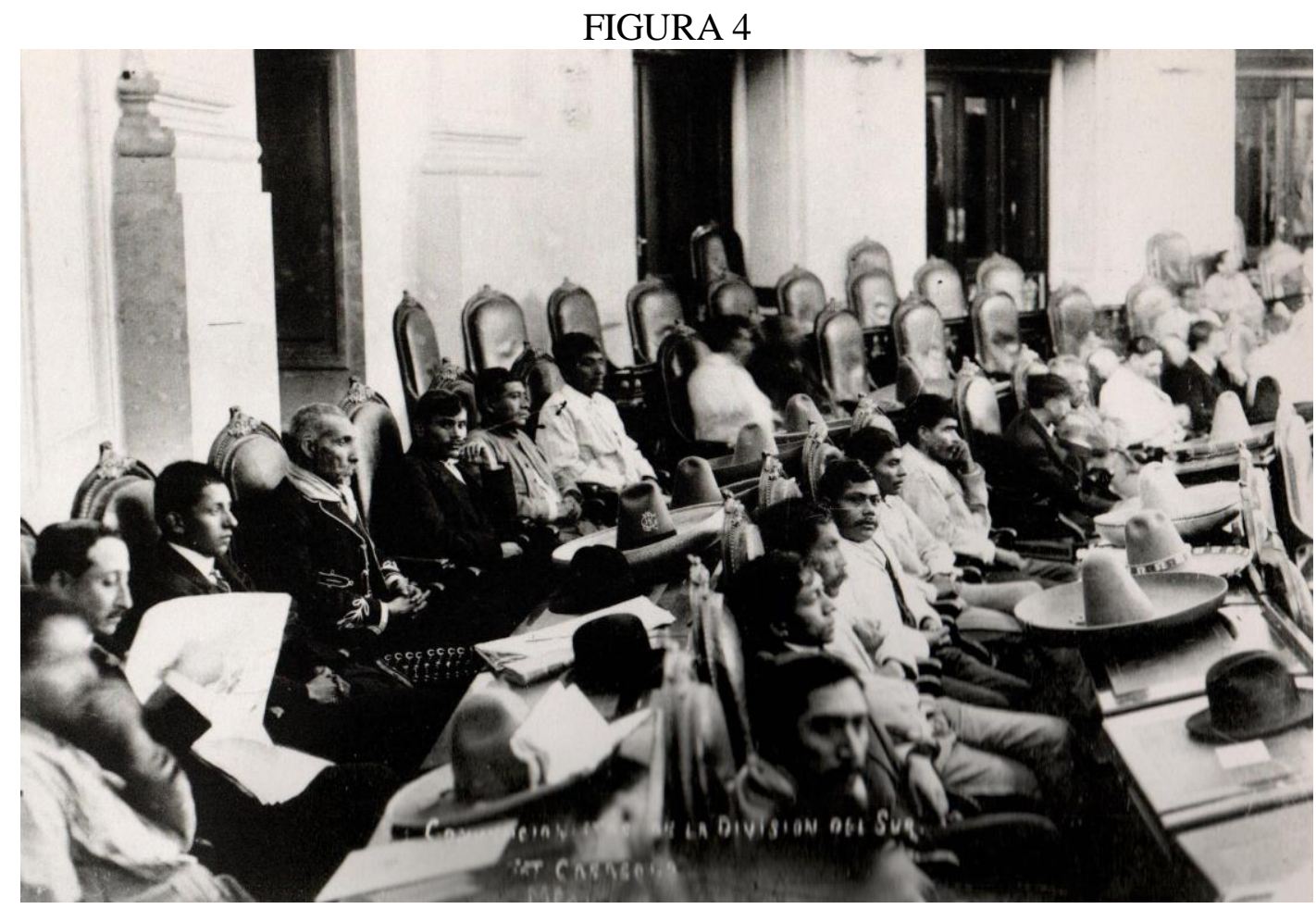

Delegados zapatistas en la Convención, discutiendo el programa de gobierno, en su tercera etapa de la Ciudad de México, enero de 1915. Foto de Agustín Víctor Casasola. Tomado de Historia Gráfica de la Revolución Mexicana, Vol. III, tercera edición, México, Trillas, 1992, p. 964.

En la Cámara de Diputados de la capital, -en su quinta etapa-, del 22 al 24 de marzo y luego el día 26, continuó la discusión de varios artículos del Proyecto de Programa de Reformas Político-Sociales de la Revolución, que habían quedado pendientes: se refrendó adoptar el parlamentarismo como sistema de gobierno en la República; se aprobó el reconocimiento legal de los sindicatos y sociedades de obreros, dependientes o empleados, así como dar garantías a los trabajadores, concediéndoles amplia libertad de huelga y de boycotaje; establecimiento del divorcio de manera formal, protección de los hijos naturales y su reconocimiento ante la ley. Algunos artículos quedaban momentáneamente sin decisión, pues se terminaba el tiempo destinado a su discusión. Abril fue de poca actividad deliberativa, en contraste con la intensidad con la que se combatió en los campos de batalla. El 8 de julio,

\section{GANPHLAC}

Revista Eletrônica da ANPHLAC, ISSN 1679-1061, №. 23, p. 05-28, Jul./Dez., 2017.

http://revista.anphlac.org.br 
ante la amenaza de las fuerzas constitucionalistas, la Convención decide trasladarse a Toluca, Estado de México, ciudad en la que no se pueden tomar acuerdos válidos ante la falta de quórum; reestructurada a instancias del general Emiliano Zapata, la Convención termina el estudio del Proyecto de Reformas de la Revolución a finales de septiembre. Ante el nuevo amago del enemigo, el organismo deliberativo itinerante acuerda disolverse, el grupo villista se va hacia el norte, el zapatista al sur, a Cuernavaca y más tarde a Jojutla, Morelos, lugar donde se publica, el 18 de abril de 1916, el documento definitivo denominado Programa de Reformas Político-Sociales de la Revolución; esta fue la última etapa, aunque ya la Convención se reducía únicamente a los elementos del Ejército Libertador del Sur (AMAYA, 1975, p. 258274, 276-279, 285-291, 307, 453-463; ALESSIO, 1989, p. 473-474).

Como se puede apreciar, la trashumancia de la Convención vuelve muy intermitente la discusión del programa revolucionario. No cabe duda que la impronta campesina y popular que nutría a los contingentes zapatistas y villistas estaba animada de una fuerza tan vigorosa que sobrevivió a las derrotas de sus ejércitos y se consagró en los artículos del Programa de Reformas Político-Sociales de la Revolución, tal como lo prueba Felipe Arturo Ávila en su reciente libro Las corrientes revolucionarias y la Soberana Convención (2014, p. 421-514). ${ }^{5}$

\section{Congreso Constituyente}

Venustiano Carranza, Primer Jefe del Ejército Constitucionalista y Encargado del Poder Ejecutivo (quien desconoció el gobierno y soberanía de la Convención Revolucionaria, acusándola de ilegal, ilegítima y no representativa), fue expidiendo y poniendo en vigor -a fines de 1914 y principios de 1915, con su Ley Agraria del 6 de enero relativa a Restitución y Dotación de Ejidos a los pueblos- una serie de leyes, disposiciones y medidas encaminadas a dar satisfacción de las necesidades económicas, sociales y políticas del país, que en su conjunto fueron configurando un programa de reformas revolucionarias (PALAVICINI, 1980, pp. 1718). ${ }^{6}$

\footnotetext{
${ }^{5}$ Véase los capítulos 10 y 11 de AVILA, 2014, quien analiza a profundidad y en su contexto histórico la discusión del Programa de Reformas Políticas y Sociales: la cuestión obrera, el divorcio y la cuestión de la mujer, el problema educativo, el problema del ejército, el Comité de Salud Pública, la cuestión agraria, el problema laboral, la justicia institucional y el de los funcionarios y empleados públicos.

${ }^{6}$ En realidad el carrancismo arrebató, en tanto estrategia de guerra, la bandera del Plan de Ayala de los zapatistas, pues en esencia las Adiciones al Plan de Guadalupe del 12 de diciembre de 1914 habla de "leyes agrarias que favorezcan la formación de la pequeña propiedad, disolviendo los latifundios y restituyendo a los pueblos las tierras de que fueron injustamente privados", además de incorporar "leyes fiscales encaminadas a
}

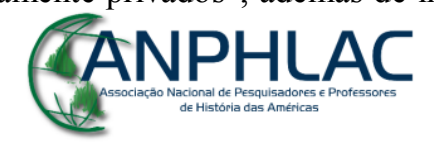

Revista Eletrônica da ANPHLAC, ISSN 1679-1061, №. 23, p. 05-28, Jul./Dez., 2017.

http://revista.anphlac.org.br 
Según Félix F. Palavicini, a la sazón Encargado del Despacho de la Secretaría de Instrucción Pública y encargado de la Sección de Legislación Social en el gobierno carrancista, fue él quien hizo notar al Primer Jefe que no tenía autoridad suficiente para hacer reformas constitucionales, además de que -dice en su Historia de la Constitución de 1917- aplicarlas y legitimarlas era un proceso largo y complicado, por lo que era mejor convocar a un nuevo Congreso Constituyente extraordinario que revisara y corrigiera los defectos de la Constitución de 1857 e incorporara las reformas necesarias del programa revolucionario de modo que respondiesen a las aspiraciones nacionales (1980, p. 20-29).

Fue así que Carranza publicó el 14 de septiembre de $1916^{7}$ la convocatoria al Congreso Constituyente, a realizarse en la ciudad de Querétaro, para concretizar un programa concreto, “acallar" lo que él llamaba "la reacción” o enemigos de la revolución, dando al país una nueva Constitución o norma jurídica que determinase la organización fundamental del Estado.

La sede del Congreso Constituyente de Querétaro fue la Academia de Bellas Artes, los primeros días, y luego lo fue el Teatro Iturbide (después llamado De La República). Allí, en esa ciudad, se perfilaron dos grupos claramente diferenciados: el de Carranza, cuyos colaboradores cercanos eran civiles (abogados e ingenieros, las cabezas más visibles eran el diputado Félix F. Palavicini y Luis M. Rojas, éste presidente del Congreso), con tendencias liberales moderadas cuyo proyecto apuntaba más a realizar reformas políticas y garantizar los derechos individuales de los ciudadanos; y el del general Álvaro Obregón, configurado por una élite militar (la cabeza más visible era el general Francisco J. Múgica, quien presidía la influyente Segunda Comisión de Constitución, cuyo prestigio procedía de las batallas ganadas en los campos de pelea, que entendía -nos dice Werner Tobler- que "las sacudidas de una guerra civil de muchos años, la movilización consiguiente de considerables sectores de la población mexicana y la creación de múltiples grupos nuevos de poder a partir a partir de los

obtener un sistema equitativo de impuestos a la propiedad raíz; legislación para mejorar la condición del peón rural, del obrero, del minero y, en general, de las clases proletarias; establecimiento de la libertad municipal como institución constitucional; bases para un nuevo sistema de organización del ejército; reformas de los sistemas electorales para obtener la efectividad del sufragio; organización del Poder Judicial independiente, tanto en la Federación como en los Estados; revisión de las leyes relativas al matrimonio y al Estado Civil de las personas...; revisión de las leyes relativas a la explotación de minas, petróleo, aguas, bosques y demás recursos del país para destruir los monopolios creados por el antiguo régimen y evitar que se formen otros en lo futuro..."

${ }^{7}$ Para entonces el carrancismo, en la lucha de facciones, ya había derrotado militarmente a sus adversarios: a los villistas, casi por completo, quedando reducidos a guerra de guerrillas en Chihuahua, mientras que los zapatistas resistían pero estaban acotados en su propio territorio, en algunos pueblos y montañas del estado de Morelos; ambas facciones habían dejado de ser un peligro para su gobierno y hegemonía (WERNER, 1994, p. 321-346).

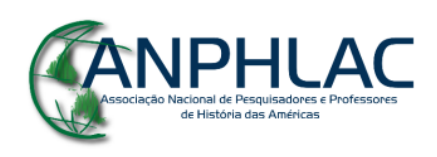

Revista Eletrônica da ANPHLAC, ISSN 1679-1061, №. 23, p. 05-28, Jul./Dez., 2017.

http://revista.anphlac.org.br 
acontecimientos revolucionarios, requerían de una política nueva", encaminada a implementar reformas sociales y económicas más amplias. (1994, p. 349). En realidad, se trataba de dos estrategias diferentes para la estabilización política interna.

A final de cuentas se impuso en los largos y agitados debates el ala más radical o jacobina, lo cual quedó de manifiesto en los artículos: $3^{\circ}$ que establece la posición del Estado sobre el sistema de enseñanza, eliminando toda influencia de la Iglesia en la educación primaria; el 27, que habla del reordenamiento de la tenencia de la tierra y el derecho de la nación sobre la riqueza del subsuelo, esto es, regula el amplio campo de los bienes raíces, el derecho del agua y lo relativo al petróleo, minerales, etcétera; el 123, conjunto de disposiciones para la protección de los trabajadores que reglamenta las relaciones laborales; y el 130, que regula la relación Iglesia-Estado (WERNER, 1994, p. 349-365).

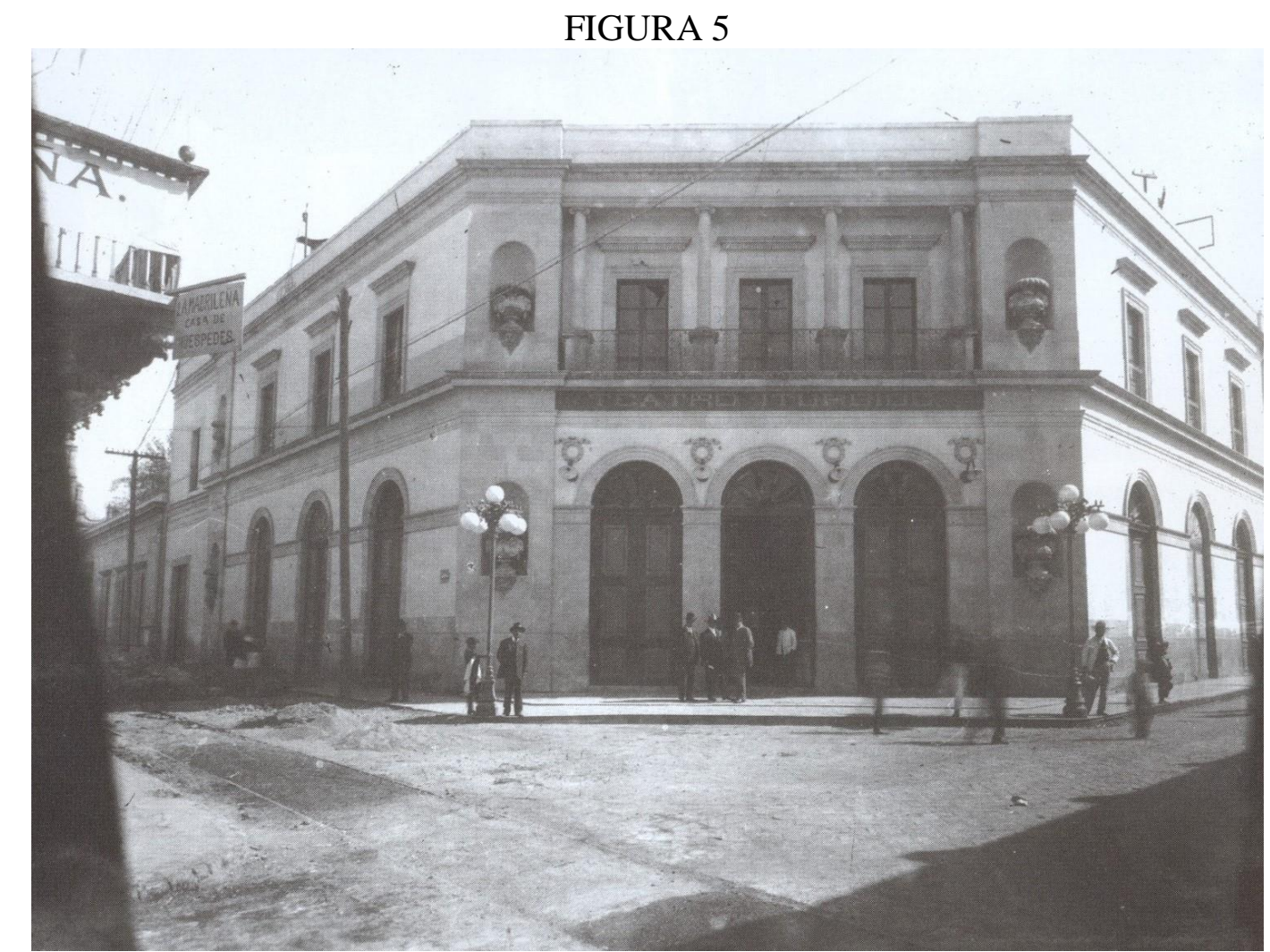

Teatro Iturbide (De la República), sede de los diputados constituyentes de Querétaro. Tomado de Historia Gráfica del Congreso Constituyente 1916-1917. José Mendoza, fotógrafo, México, INEHRM/Secretaría de Cultura, 2016 [Centenario 1917-2017 Constitución Política de los Estados Unidos Mexicanos], p. 39. Autor: José Mendoza.

\section{GANPHLAC}

Revista Eletrônica da ANPHLAC, ISSN 1679-1061, №. 23, p. 05-28, Jul./Dez., 2017.

http://revista.anphlac.org.br 


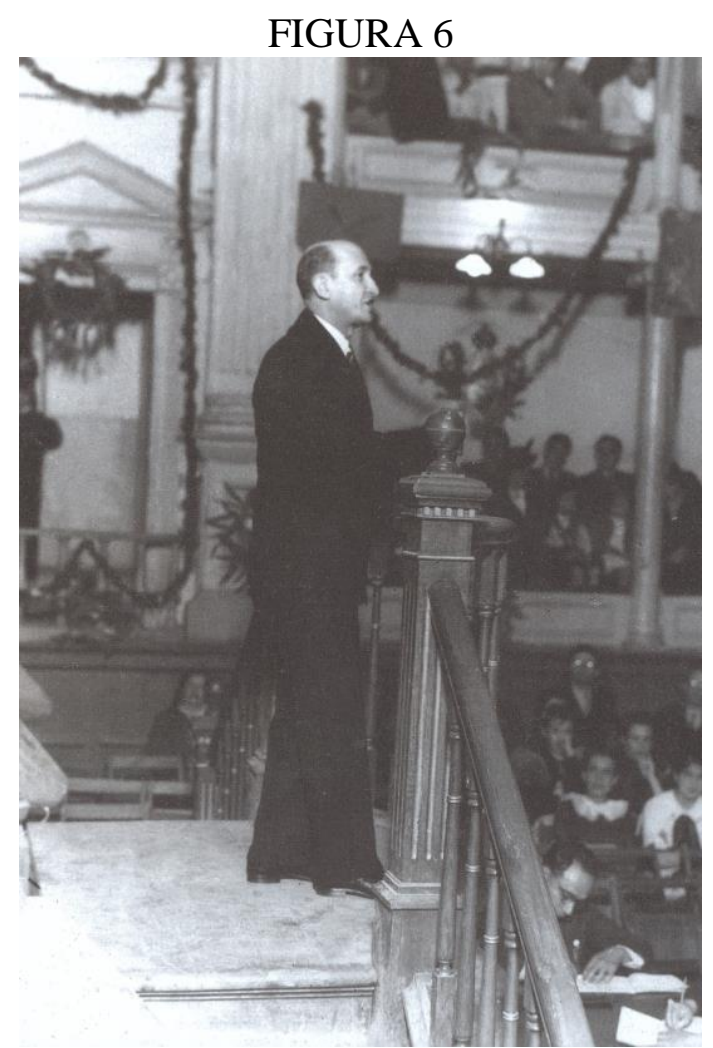

Ingeniero Félix F. Palavicini en la tribuna, hablando sobre el artículo 3o. constitucional. Historia gráfica del Congreso Constituyente 1916-1917..., p. 70. Autor: José Mendoza.

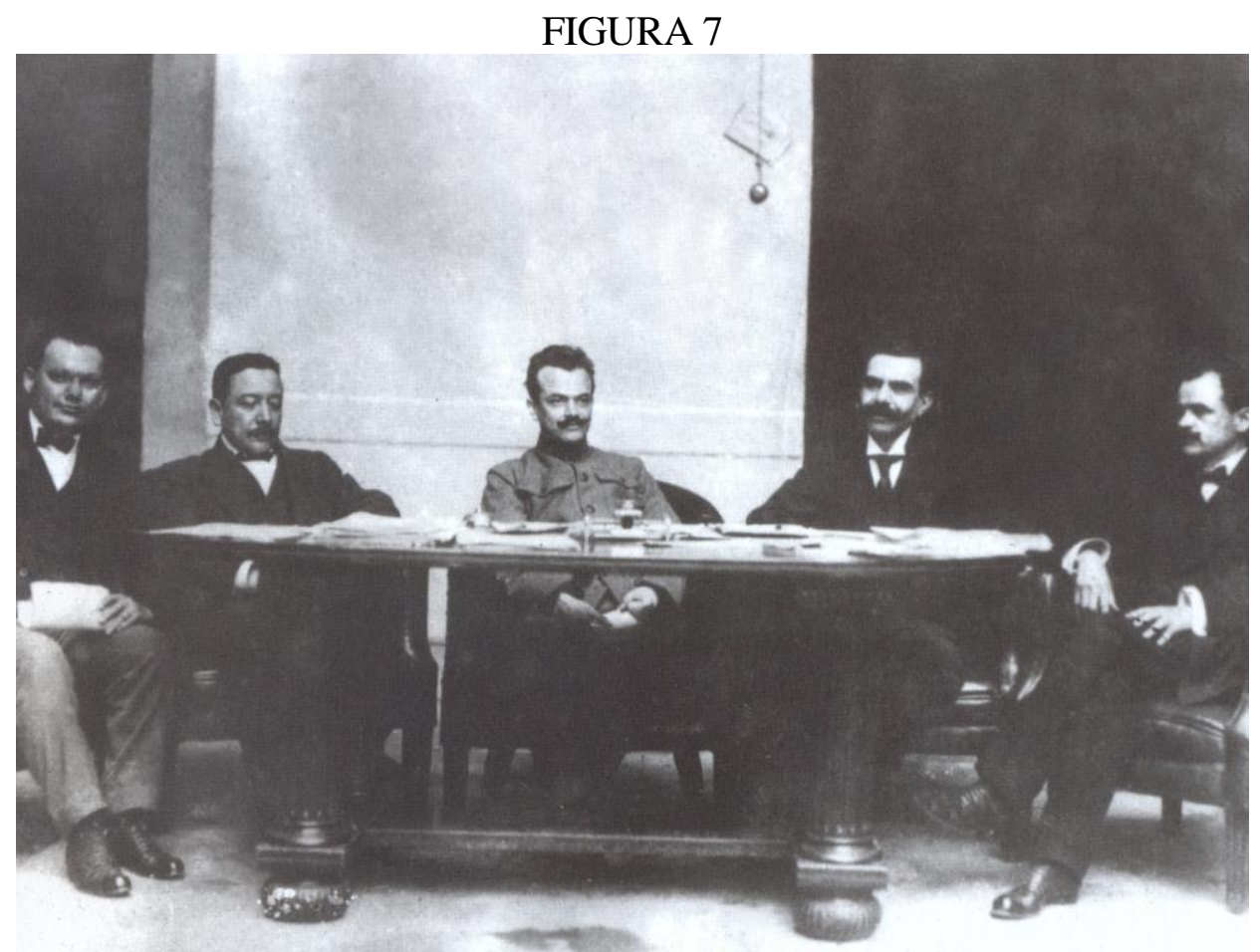

Segunda comisión de estudio de puntos constitucionales, en que figuró el general Francisco J. Múgica, miembro del ala radical del constituyente. Historia gráfica del Congreso Constituyente 1916-1917..., p. 38. Autor: José Mendoza.

\section{GANPHLAC}

Revista Eletrônica da ANPHLAC, ISSN 1679-1061, №. 23, p. 05-28, Jul./Dez., 2017.

http://revista.anphlac.org.br 


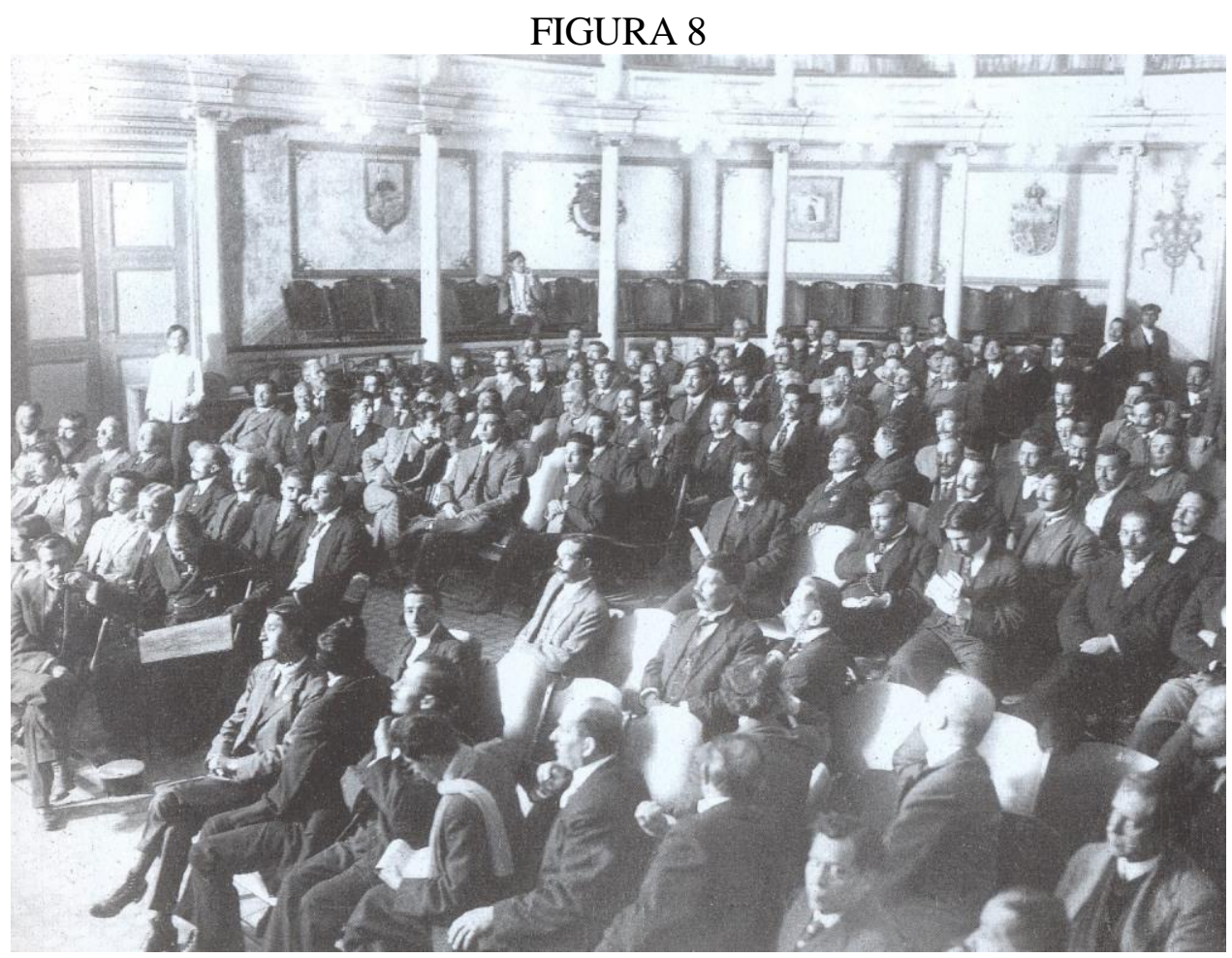

Discusión del artículo 123, aspecto del salón. Historia gráfica del Congreso Constituyente 1916$1917 \ldots$, p. 74. Autor: José Mendoza.

\section{El fotógrafo del Constituyente de Querétaro}

Al igual que en octubre-noviembre de 1914 en Aguascalientes cuando la Convención Revolucionaria, dada la importancia del Congreso Constituyente de Querétaro entre noviembre de 1916 y febrero de 1917, la prensa fue un actor central para dar a conocer el proceso del evento así como los múltiples sucesos que giraron a su alrededor; varias empresas periodísticas nacionales (algunas oficialistas y otras comerciales) e internacionales mandaron a sus corresponsales a cubrir la información, en tanto que los periódicos locales hicieron lo propio. Resume José Guadalupe Ramírez ${ }^{8}$ que se hicieron presentes:

La Opinión, El Diario de los Debates, El Constituyente, El Zancudo, El Pueblo, El Demócrata, El Universal, The New York Times, The Associated Press, El Camote y La

\footnotetext{
${ }^{8}$ Guadalupe Ramírez Álvarez fue un bibliófilo originario del estado de Querétaro, abogado y aficionado a la historia local, se dedicó a reunir una serie de libros y periódicos de diferentes épocas, conformando un acervo bibliográfico y hemerográfico de singular importancia para la reconstrucción de la historia de la entidad. Una buena parte del mismo, lo donó a la Universidad Autónoma de Querétaro y hoy en día, todavía se encuentra en proceso de clasificación. En sus diversas publicaciones dio cuenta no sólo de los sucesos más representativos o momentos clave de la historia queretana, sino también de múltiples personajes destacados, lugares representativos, anécdotas, periódicos, personajes y eventos; de manera destacada rescató la celebración del Congreso Constituyente de 1916-1917. Véase ESPINOSA BLAS y LANDA FONSECA, 2016, p. 7677.
}

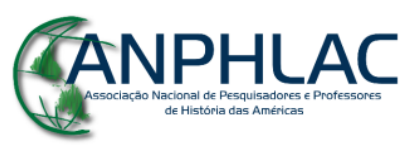

Revista Eletrônica da ANPHLAC, ISSN 1679-1061, №. 23, p. 05-28, Jul./Dez., 2017.

http://revista.anphlac.org.br 
Sombra de Arteaga, etc. Así, por estas publicaciones, modestas algunas, de polendas otras, el Constituyente, voz del pueblo que anhelaba paz y justicia, se hizo escuchar por ese pueblo al que representaba. ${ }^{9}$

Respecto a la memoria gráfica, uno de los fotógrafos que captó los momentos culminantes de los escenarios, discursos, debates, proyectos, trabajos de las comisiones, toma de protesta de los diputados, llegada y presencia del Primer Jefe Encargado del Poder Ejecutivo, aprobación de los artículos constitucionales, diputaciones por estado, retratos individuales, clausura del Congreso Constituyente y momentos de esparcimiento, fue José Mendoza, originario de la Ciudad de México y ferviente partidario de Venustiano Carranza pues cubrió sus giras desde 1914 hasta 1917 y luego de su muerte en 1920 dejó de tomar fotografías. Dice Aurelio de los Reyes que "en la fotografía de Mendoza predomina la intención testimonial, dirigida a guardar memoria visual" (2016, p. 14) de los protagonistas para la posteridad; es evidente que muchas imágenes carecen de calidad, están desenfocadas, borrosas y están mal encuadradas, pues se priorizó "el valor testimonial sobre el valor estético", además de que contó con pocos espacios y escasa movilidad, lo que le difícultó las maniobras para tomar fotos desde distintos y variados puntos de vista (2016, p. 17).

\section{Convención y Constitución}

Dentro de la abundante historiografía sobre la Revolución mexicana, uno de los temas menos socorridos es el de la llamada Soberana Convención de Aguascalientes. El historiador austriaco Friedrich Katz (1999, p. 440) advierte que el conflicto que enfrentó a las fuerzas de la Convención Revolucionaria, encabezadas por Francisco Villa y Emiliano Zapata, contra los ejércitos de la facción constitucionalista, cuyos dirigentes principales eran Venustiano Carranza y Álvaro Obregón, es tal vez el tema más debatido y polémico así en la historia como en la historiografía de la llamada Revolución mexicana.

Pero ¿Cuál es la relación que se establece entre la Convención Revolucionaria y la Constitución de 1917?

\footnotetext{
${ }^{9}$ José Guadalupe Ramírez Álvarez, La Constitución de Querétaro, Querétaro de la Constitución, Querétaro, Ediciones del Gobierno del Estado, 1985, pp. 19-25. Citado en ESPINOSA BLAS y LANDA FONSECA, 2016, p. 77
}

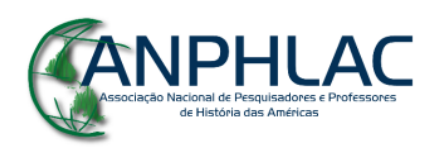

Revista Eletrônica da ANPHLAC, ISSN 1679-1061, №. 23, p. 05-28, Jul./Dez., 2017.

http://revista.anphlac.org.br 
Respecto a las ideas que formaron parte del Programa de Reformas Político-Sociales de la Revolución, distintas generaciones de historiadores advierten que algunas de ellas pasaron, indirectamente, a la Carta Magna que nos rige. Basta revisar lo que escribieron autoresprotagonistas como Federico Cervantes, Vito Alessio Robles o Florencio Barrera Fuentes; o bien lo investigado desde la academia por historiadores extranjeros y mexicanos como Robert Quirk y Luis Fernando Amaya; asimismo autores más contemporáneos que emplean nuevos abordajes teórico-metodológicos como Eugenia Meyer, Hans Werner Tobler, Arnaldo Córdova, Enrique Florescano, Felipe Arturo Ávila Espinosa, entre otros.

El coronel Federico Cervantes, delegado convencionista que militó en las filas de la División del Norte y que tuvo una destacada participación en las discusiones del programa de gobierno, apunta que ese organismo cumplió con su misión histórica al emitir y publicar, primero en Toluca y después en Jojutla, el Programa de Reformas Económicas, Políticas y Sociales de la Convención Nacional Revolucionaria; aunque Cervantes no aclara la manera en que se publicó en México, asienta que "ha sido poco conocido históricamente, por más que si llegó a manos de los carrancistas" (2000, p. 460), dando a entender que también lo pudieron conocer los constituyentes de Querétaro; menciona, además, cómo fue reproducido y dado a conocer en los Estados Unidos de Norteamérica y que:

Por aquel entonces, en el destierro, en 1916, un grupo de cuatro convencionistas lo publicamos incluido en un folletito que trabajosamente reprodujimos a máquina. El número de ejemplares apenas llegaría a cincuenta. Pero las ideas, como las mies, germinan: a los cuarenta años [de distancia, es decir hacia 1956] lo hemos visto reproducido y comentado en la prensa de El Paso, Texas, y en la de la capital de la República por el Prof. de Historia John H. Mac Neely (CERVANTES, 2000, p. 460).

Vito Alessio Robles, quien fuera secretario de la Convención en la etapa de Aguascalientes, en términos lacónicos anota al final de su obra: "Puede asegurarse que esta asamblea tuvo el carácter de preconstituyente y señaló los principios que fueron adoptados en la Constitución de 1917” (1989, p. 474). En ese sentido, el profesor y diputado en el Congreso Constituyente de Querétaro Florencio Barrera Fuentes afirma, sin aportar pruebas, que a dicho congreso "concurrieron muchos revolucionarios que hicieron su aprendizaje parlamentario en la Convención" (1977, p. 16-17); en realidad no ocurrió tal cosa, pues si bien asistió algún carrancista $^{10}$ que estuvo en la primigenia etapa de la Convención, lo cierto es que a dicho

\footnotetext{
${ }^{10}$ Los únicos que asistieron al Congreso Constituyente de Querétaro fueron los carrancistas: general José Inocente Lugo y coronel Samuel M. de los Santos Rivera. El primero estuvo en la etapa de la Convención en Aguascalientes en octubre de 1914, donde fue aprobada su credencial con representación propia y luego en el
}

\section{GANPHLAC}

Revista Eletrônica da ANPHLAC, ISSN 1679-1061, №. 23, p. 05-28, Jul./Dez., 2017.

http://revista.anphlac.org.br 
Congreso no fueron invitados villistas, zapatistas y desde luego ex huertistas. Así lo dice categóricamente Félix F. Palavicini, carrancista y diputado al congreso constituyente: "Como era lógico esperar, la convocatoria a un congreso constituyente provocó reacciones dentro del partido, ya denominado popularmente como carrancista y, con mayor razón, entre los adversarios. Sumábanse en oposición al congreso los derrotados del villismo, del zapatismo y todas las facciones conservadoras o reaccionarias del porfirismo, reyismo, felixismo y huertismo" (1980, p. 45); es más, sin sonrojo admite que es ilógico invitar a los enemigos al banquete, esto es, para tomar parte en la confección de sus nuevas leyes: "La Constitución de 1917 es obra de un partido...Todas las constituciones, esencialmente las que resultan de una revolución, son constituciones hechas por un partido, el partido triunfante” (1980, p. 51).

Por otro lado Luis Fernando Amaya en tono rotundo asevera que el Programa de Gobierno de la Convención cumplió con su cometido de señalar las metas de la Revolución Mexicana: "El mensaje convencionista, apagado por el estruendo de los cañones, volvió a oírse en los debates del Congreso Constituyente de 1917. Ha seguido escuchándose, cual voz que emerge del subsuelo revolucionario, en cada momento crucial de la vida de México, señalando siempre una ruta invariable cual aguja magnética de la mexicanidad" (1975, p. 442).

Por su parte, el historiador estadounidense Robert Quirk concluye que los ideales de reforma social por los que lucharon el villismo y el zapatismo, esto es, los anhelos y aspiraciones de la Convención, "en 1916 y 1917, en Querétaro... se reflejaron en las estipulaciones radicales de la nueva Constitución. Y durante los veinticinco años siguientes, las reformas agrarias del zapatismo fueron la base de los programas de gobierno para la reconstrucción rural" (1989, p. 229).

Aunque brillaron por su ausencia los convencionistas en el constituyente de Querétaro, nos dice el investigador austriaco Hans Werner Tobler, no por ello se puede "negar la influencia indirecta de villistas y zapatistas sobre el transcurso del Congreso. Especialmente las demandas agrarias defendidas con gran tenacidad por los zapatistas establecieron este

congreso constituyente de Querétaro, donde formó parte de la Comisión de Estudio del Artículo 27; véase las fotos de las páginas 61 y 72 en Historia Gráfica del Congreso Constituyente 1916-1917. José Mendoza, fotógrafo, México, INEHRM/Secretaría de Cultura, 2016 [Centenario 1917-2017 Constitución Política de los Estados Unidos Mexicanos]. El segundo se desempeñó como secretario de la Convención Revolucionaria en la etapa de Aguascalientes; fue como diputado constituyente por el 1er. Distrito electoral de San Luis Potosí, y participó en la discusión del artículo 82 constitucional. Véase Diccionario de los diputados constituyentes de 1917, 2016, p. 140, [Centenario 19172017 Constitución Política de los Estados Unidos Mexicanos]. Disponible en https://archivos.juridicas.unam.mx/www/bjv/libros/9/4372/7.pdf. Consultado el 17 de mayo de 2017. Cfr. Constitución Política de los Estados Unidos Mexicanos, 2016, p. 92; el artículo 82 es el relativo a los requisitos para ser Presidente de la República.

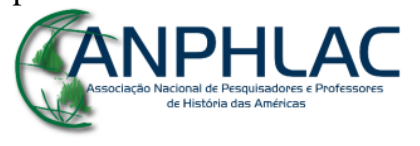

Revista Eletrônica da ANPHLAC, ISSN 1679-1061, №. 23, p. 05-28, Jul./Dez., 2017.

http://revista.anphlac.org.br 
problema en la conciencia política general a tal grado que influyeron persistentemente en las discusiones en torno al artículo 27, si bien de manera indirecta" (1994, p. 347-348).

La investigadora Eugenia Meyer asienta que "Las ideas y los ideales de la Convención [contenidos en el Programa de Reformas Político-Sociales de la Revolución] se dieron a conocer de muchas formas...", las cuales son un cúmulo de "ideas de extraordinaria riqueza doctrinal, que tanto influyó en el Constituyente de 1916 y que éste no pudo superar" (1990, p. 142).

Felipe Arturo Ávila, historiador mexicano, afirma con justeza que el Programa de Gobierno de la Convención es básicamente el proyecto revolucionario zapatista, con ligeras modificaciones derivadas de la presencia de los delegados de la División del Norte. Dicho documento contiene, predominantemente, las propuestas ideológicas y políticas más avanzadas y sólidas del zapatismo, quienes impusieron su hegemonía a los norteños en los debates de la Soberana Convención Revolucionaria, así como la incrustación de algunas concepciones de tinte conservador que los villistas lograron que se aprobaran ante el predominio abrumador de los sureños. En conjunto, se trata del cuerpo más avanzado y completo de principios, postulados y medidas sobre los principales problemas del país, asienta Ávila Espinosa, en comparación de cuantos se elaboraron en el transcurso de la Revolución, incluyendo la propia Constitución (1991, p. 197, 205, 212, 217).

El recientemente fallecido politólogo mexicano Arnaldo Córdova advierte que el Programa de Reformas Político-Sociales de la Revolución fue "el mortero en el que se fundieron las exigencias y las demandas" populares, (citado en FLORESCANO, 2005, p. 283) cuya fuerza afloró en las sesiones del Congreso Constituyente de 1917, reunido en la ciudad de Querétaro; finalmente, y en este orden de ideas, añade Enrique Florescano:

En un acto sin precedentes, los diputados ahí reunidos recogieron las reivindicaciones agrarias, laborales y democráticas sustentadas por los diversos sectores de la población y las plasmaron en el acta constitutiva del Estado fundado por la Revolución. Así, el ancestral problema de la propiedad territorial adoptó una nueva definición en el artículo 27... [que] en su parte sustantiva apoyaba el fraccionamiento de los latifundios... Por su parte, el artículo 123, estableció la jornada máxima de trabajo diurno, nocturno y de las mujeres y los menores; el descanso semanal; el salario mínimo; la participación de utilidades; el patrimonio familiar; y las condiciones indispensables que garantizaran la seguridad y la salud de los trabajadores (2005, p. 283-284).

Por último, nos dice Patricia Galeana, quien actualmente está al frente del Instituto Nacional de Estudios Históricos de las Revoluciones de México: “A pesar de la derrota política

\section{CANPHLAC}

Revista Eletrônica da ANPHLAC, ISSN 1679-1061, №. 23, p. 05-28, Jul./Dez., 2017.

http://revista.anphlac.org.br 
y militar, la Convención dejó un importante legado político que fue recogido parcialmente, en el nuevo Congreso Constituyente mexicano de 1917” (2014, p. 20).

\section{Conclusión}

El Programa de Reformas Político-Sociales de la Revolución -subdividido en 5 artículos para la "cuestión agraria"; 3 para la "cuestión obrera"; 2 para "reformas sociales"; 20 para "reformas administrativas"; 7 para "reformas políticas"; y 3 para "artículos transitorios" $" 1$ - es un cuerpo programático muy avanzado en materia de reformas políticas, económicas y sociales. Desde luego que dicho programa fue un semillero de ideas que, como ha quedado anotado, indirectamente repercutieron en las discusiones de algunos de los artículos más importantes de la Carta Magna que nos rige.

La Soberana Convención Revolucionaria, por último, fue también un laboratorio, un campo de experimentación cuyos resultados prácticos inmediatos fueron un rotundo fracaso para su causa. Sin embargo, la riqueza de los debates, la identificación y clarificación de los problemas del país y la expedición del documento Programa de Reformas Político-Sociales de la Revolución fueron un triunfo teórico en materia de ideas, algunas de las cuales quedaron plasmadas en la Constitución de 1917, mismas que fueron materializadas años después (VILLEGAS, 1994, p. 261-269). Arnaldo Córdova, analista y politólogo, apuntó: “Desde mi punto de vista, ni siquiera el Congreso Constituyente de 1916 a 1917 presenta la pasmosa riqueza de ideas y de planteamientos que ofrece la Convención" (1990, p. 131). Me adhiero a lo asentado por él:

Pero como ha sido reconocido desde siempre, las utopías forman parte del espíritu transformador de la sociedad. Sin ellas no nos moveríamos. Todo movimiento de transformación social es en gran medida utópico, hasta que no se realiza o se comprueba que no puede realizarse. Y aun así la utopía queda para la historia como un ejemplo que está siempre presente y que alimenta la imaginación y el deseo de cambiar de los hombres. Desde este punto de vista, tampoco puede haber duda de que la experiencia de la Soberana Convención Revolucionaria sigue siendo hoy un tesoro invaluable de nuestra cultura política nacional y así deberemos preservarlo (p. 131).

Son múltiples las posibles lecciones que nos dejó la Convención Revolucionaria de hace poco más de cien años, organismo que imaginó una sociedad más justa, más próspera y

\footnotetext{
${ }^{11}$ El documento en extenso "Programa de Reformas Político-Sociales de la Revolución aprobado por la Soberana Convención Revolucionaria", en Jojutla, Morelos, el 18 de abril de 1916, puede consultarse en AMAYA, 1975, p. 459-463.
}

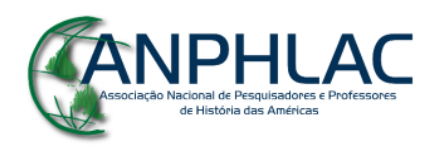

Revista Eletrônica da ANPHLAC, ISSN 1679-1061, №. 23, p. 05-28, Jul./Dez., 2017.

http://revista.anphlac.org.br 
con mayor soberanía. Hoy en día hace falta un conjunto de grandes ideas que apunten hacia un nuevo proyecto nacional con el que se sientan identificadas las distintas corrientes políticas del país, aceptable para la mayoría de los mexicanos, que les dé la certeza de un futuro digno, mejor que el presente, que inyecte una cierta dosis de utopía.

La mayoría de los autores que han estudiado el tema de la Convención, sostienen que las ideas más radicales del Programa de Reformas Político-Sociales de la Revolución, quedaron plasmadas en distintos artículos de la Constitución de 1917. Sin embargo, podemos concluir que no existe un estudio profundo que haga un cotejo puntual y riguroso de ambos documentos, con base en los diarios de los debates de ambos procesos, es decir, de los convencionistas (en las etapas de México, Aguascalientes, Cuernavaca, Toluca y Jojutla) contra lo discutido por los Constituyentes de Querétaro.

En ese sentido, tampoco se ha hecho una investigación en que se compare las fotografías de uno y otro evento, en que se señale similitudes y diferencias, mostrando características formales, escenarios, las imágenes que fueron publicadas en la prensa nacional e internacional y las que se quedaron archivadas, así como las trayectorias de los fotoperiodistas y empresas que los contrataron. Sería interesante un ejercicio comparativo del discurso visual de la Convención Revolucionaria y el Congreso Constituyente, precursores de los derechos del pueblo de México.

\section{FUENTES CONSULTADAS}

ALESSIO, Vito. La Convención Revolucionaria de Aguascalientes. México: INEHRM, 1989. AMAYA, Luis. La Soberana Convención Revolucionaria, 1914-1916. México: Trillas, 1975

ÁVILA, Felipe. El pensamiento económico, político y social de la Convención de Aguascalientes. México: INEHRM/Instituto Cultural de Aguascalientes, 1991.

ÁVILA, Felipe. Las corrientes revolucionarias y la Soberana Convención. México: H. Congreso del Estado de Aguascalientes-LXII Legislatura-Universidad Autónoma de Aguascalientes-El Colegio de México-Instituto Nacional de Estudios Históricos de las Revoluciones de México-Secretaría de Educación Pública, 2014.

BARRERA, Florencio, Introducción. En Crónicas y debates de la sesiones de la Soberana Convención Revolucionaria. México: INEHRM, 1965, p. 5-17.

\section{GANPHLAC}


BERLANGA, David. Pro-Patria. Aguascalientes: Tipografía Escuela de Artes y Oficios, 1914.

Constitución Política de los Estados Unidos Mexicanos. México: Berbera Editores S.A. de C.V., 2016.

CERVANTES, Federico. Francisco Villa y la Revolución. México: INEHRM, 2000.

CÓRDOVA, Arnaldo. La herencia de la Soberana Convención Revolucionaria. En La soberana Convención Revolucionaria en Aguascalientes. Aguascalientes: Instituto Cultural de Aguascalientes, 1990, p. 130-133.

DE LOS REYES, Aurelio, "estudio introductorio", en Historia Gráfica del Congreso Constituyente 1916-1917. José Mendoza, fotógrafo, México, INEHRM/Secretaría de Cultura, 2016 [Centenario 1917-2017 Constitución Política de los Estados Unidos Mexicanos], pp. 13-24.

Diccionario de los diputados constituyentes de 1917. México: Instituto Nacional de Estudios Históricos de las Revoluciones de México-Secretaría de Cultura-Siglo XXI Editores, 2016, [Centenario 19172017 Constitución Política de los Estados Unidos Mexicanos]. Disponible en https://archivos.juridicas.unam.mx/www/bjv/libros/9/4372/7.pdf. Consultado el 17 de mayo de 2017.

ESPINOSA BLAS, Margarita; LANDA FONSECA, Cecilia del Socorro. A cien años del constituyente mexicano de 1917. La visión de El Zancudo, periódico satírico de Querétaro". Caleidoscopio. Revista de Ciencias Sociales y Humanidades, Universidad Autónoma de Aguascalientes, Aguascalientes, Ags., No. 35, agostodiciembre de 2016, pp. 75-100.

FLORESCANO, Enrique. Imágenes de la Patria. México: Taurus, 2005.

GALEANA, Patricia. Asamblea Revolucionaria. En ÁVILA, F. Las corrientes revolucionarias y la Soberana Convención. México: H. Congreso del Estado de Aguascalientes-LXII Legislatura-Universidad Autónoma de Aguascalientes-El Colegio de México-Instituto Nacional de Estudios Históricos de las Revoluciones de México-Secretaría de Educación Pública, 2014, p. 17- 20.

\section{CANPHLAC}

Revista Eletrônica da ANPHLAC, ISSN 1679-1061, №. 23, p. 05-28, Jul./Dez., 2017.

http://revista.anphlac.org.br 
KATZ, Friedrich. Pancho Villa. México: Era, 1999.

QUIRK, Robert. La revolución Mexicana, 1914-1915. La Convención de Aguascalientes. Aguascalientes: Gobierno del Estado de Aguascalientes/INEHRM, 1989.

MEDELLÍN M., José de Jesús. Las ideas agrarias de la Convención de Aguascalientes. Xalapa: Universidad Veracruzana, 2004.

MEYER, Eugenia. El oficio de recordar, memoria silente de la Soberana Convención. En La soberana Convención Revolucionaria en Aguascalientes. Aguascalientes: Instituto Cultural de Aguascalientes, 1990, p. 133-142.

PALAVICINI, Félix F., Historia de la Constitución de 1917. Integración del congreso. Debates completos, México, IINEHRM-Gobierno del Estado de Querétaro, 2 Vols., 1987 [edición facsimilar, Imprenta México, 1938].

RAMÍREZ, Luciano, Imágenes del olvido, 1914-1994. Discurso visual, manipulación y conmemoraciones de la Convención Revolucionaria de Aguascalientes, Aguascalientes, Universidad Autónoma de Aguascalientes-Centro de Ciencias Sociales y Humanidades, 2010.

RAMÍREZ, Luciano, Aguascalientes en la encrucijada de la Revolución Mexicana. David G. Berlanga y la Soberana Convención, Aguascalientes, Universidad Autónoma de Aguascalientes-Gobierno del estado de Aguascalientes-Gobierno del estado de Coahuila, 2004.

WERNER, Hans. La Revolución mexicana. Transformación social y cambio político, 18761940. México: Alianza, 1994.

VILLEGAS, Gloria, Comentarios a la ponencia El estado social de derecho. Algunos antecedentes: La Convención de Aguascalientes. En GONZÁLEZ, R. (Coord.). La formación del Estado mexicano. México: Porrúa, 1984, p. 261-269.

\section{REFERENCIAS A LAS FIGURAS}

Fig. 1 Teatro Morelos de Aguascalientes. Foto de prensa. Autor Carlos F. Muñana. El Liberal, México, D.F., 10 de octubre de 1914, p. 1

\section{GANPHLAC}


Fig. 2 La Convención Revolucionaria de Aguascalientes se declara soberana. "Los convencionistas después del juramento", El Liberal, México, D.F., 17 de octubre de 1914, p. 1. Autor Carlos F. Muñana.

Fig. 3 Presidente provisional de la República. "Gral. Eulalio Gutiérrez" y "Un aspecto de la Convención de Aguascalientes”, El Liberal, México, D.F., 8 de noviembre de 1914, p. 1. Autor Carlos F. Muñana.

Fig. 4 Delegados zapatistas en la Convención, discutiendo el programa de gobierno, en su tercera etapa de la Ciudad de México, enero de 1915. Foto de Agustín Víctor Casasola. Tomado de Historia Gráfica de la Revolución Mexicana, Vol. III, tercera edición, México, Trillas, 1992, p. 964.

Fig. 5 Teatro Iturbide (De la República), sede de los diputados constituyentes de Querétaro. Tomado de Historia Gráfica del Congreso Constituyente 1916-1917. José Mendoza, fotógrafo, México, INEHRM/Secretaría de Cultura, 2016 [Centenario 1917-2017 Constitución Política de los Estados Unidos Mexicanos], p. 39. Autor: José Mendoza.

Fig. 6 Ingeniero Félix F. Palavicini en la tribuna, hablando sobre el artículo 30. constitucional. Historia gráfica del Congreso Constituyente 1916-1917..., p. 70. Autor: José Mendoza.

Fig. 7 Segunda comisión de estudio de puntos constitucionales, en que figuró el general Francisco J. Múgica, miembro del ala radical del constituyente. Historia gráfica del Congreso Constituyente 1916-1917..., p. 38. Autor: José Mendoza.

Fig. 8 Discusión del artículo 123, aspecto del salón. Historia gráfica del Congreso Constituyente 1916-1917..., p. 74. Autor: José Mendoza.

\section{GANPHLAC}

